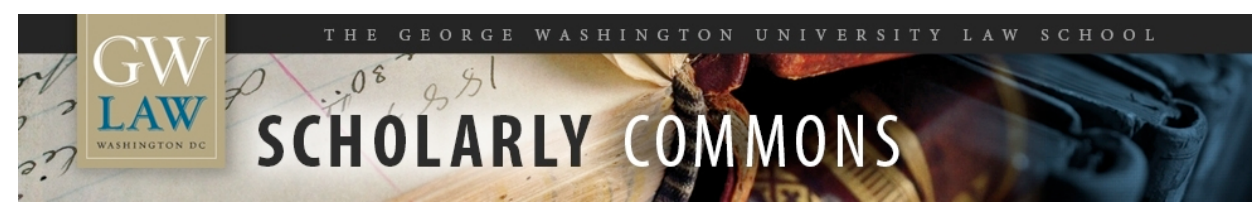

GW Law Faculty Publications \& Other Works

Faculty Scholarship

2010

\title{
Individual Rights and Transnational Networks
}

Francesca Bignami

George Washington University Law School, fbignami@law.gwu.edu

Follow this and additional works at: https://scholarship.law.gwu.edu/faculty_publications

Part of the Law Commons

\section{Recommended Citation}

Francesca Bignami, Individual Rights and Transnational Networks in COMPARATIVE ADMINISTRATIVE LAW, 632 (Susan Rose-Ackerman \& Peter L. Lindseth, eds., 2010)

This Book Part is brought to you for free and open access by the Faculty Scholarship at Scholarly Commons. It has been accepted for inclusion in GW Law Faculty Publications \& Other Works by an authorized administrator of Scholarly Commons. For more information, please contact spagel@law.gwu.edu. 


\section{Individual rights and transnational networks Francesca Bignami}

Today the paradigm of public policymaking is global, not simply national or local. Rules and standards are decided, fiscal and macroeconomic policy is determined, and policy commitments are enforced through regional and global institutions that have simultaneously built upon and transformed their national bureaucratic counterparts. Some of these institutions are traditional international organizations and tribunals, which have proliferated and expanded over recent years. Yet transnational regulatory networks, in which decisionmaking occurs through routine contacts among national civil servants, are quickly becoming the primary institutional vehicle through which cross-national policymaking occurs.

Networks marry domestic bureaucratic capacity with transnational policy ambitions and thus fall at the intersection of a number of disciplines: administrative, criminal, and constitutional law, international law, public policy studies and international relations theory. These different research traditions have begun to raise and offer answers to a number of important questions about the nature and promise of regulatory networks: Under what circumstances do states choose to cooperate through networks as opposed to international organizations and more traditional international institutions (Raustiala 2002, Eilstrup-Sangiovanni 2009)? Relatedly, what are the advantages and disadvantages of networks over more traditional forms of international cooperation (Slaughter 2004, Verdier 2009, Zaring 1998)? Under what circumstances can this form of transnational cooperation be expected to generate international convergence or other types of policy outcomes (Singer 2007)? And what types of public law metrics should be used to evaluate regulatory networks and how has the experience so far measured up to the chosen normative metric (Kingsbury et al. 2005, Slaughter 2004)?

In this short contribution, I offer some reflections on the last question. I focus on the interplay between classic liberal rights and network decisions that implicate personal freedom, property rights, and other basic interests. Safeguarding rights against arbitrary government action is one of the oldest concerns of public law - constitutional, criminal, and administrative - and therefore is necessarily at the heart of any attempt at the normative reconstruction of global governance via networks. Yet most scholarly analysis of transnational networks has tended to emphasize the agenda-setting and rulemaking activities of networks and the problem of network accountability to the broader public through transparency, the consultation of affected interests, and other devices (see, for example, Slaughter 2004). This is obviously a subject of critical importance, both because agenda-setting and rulemaking are core network activities and because public accountability in a globalized world raises difficult and novel questions about the relationship between conventional accounts of democracy and the new political terrain of globalization (see, for example, Lindseth 2006). Nonetheless, the analytically distinct aspiration of safeguarding individual rights triggers an important and distinct set of issues. By shifting the normative focus to this aspect of network activity, I seek to bring together a number 
of experiences from a variety of institutional settings to illustrate the unique issues that arise in protecting rights in the expanding domain of transnational networks.

The rest of this contribution proceeds as follows. In the next section, I offer a definition of transnational networks and give some examples of the phenomenon, with particular attention to those that can result in individualized determinations that affect liberty, property, and other types of interests. Any type of policy determination can have implications for rights, but when the institutional landscape is as fluid as with transnational networks, courts only tend to get involved and rights challenges brought at the point in the policymaking chain at which a concrete decision, affecting an individual or set of individuals, has been taken. In the third section, which contains the bulk of the analysis, I point to the difficulties triggered by the core characteristic of networks - the dispersion of decisionmaking power across government units. In particular, I discuss the issues that have arisen in the EU legal system, which has a long experience with networks designed to apply and enforce common EU policies. The conclusion suggests how this EU experience is relevant for transnational networks that operate in other international regimes.

\section{Defining regulatory networks}

In the international law and international relations literature, transnational networks are generally defined in opposition to classic treaty regimes (Eilstrup-Sangiovanni 2009, Verdier 2009). In this characterization, the actors are regulators that deal with specific policy problems, not heads of government and officials charged with representing the national interest abroad, generally located in foreign ministries. The legal instruments in which they set down their course of action are soft, informal documents such as memoranda of understanding, letters of intent, and common guidelines, not formal legal instruments such as international treaties. Network meetings and exchanges of information are conducted as necessity dictates, not set down in advance in formal treaties or fixed at the conclusion of international conferences of the parties. And, in contrast with the elaborate set of institutions and decisionmaking procedures that characterize traditional international organizations, networks often do not have any official voting rules or membership criteria; rather they proceed informally, generally by consensus and with the national configuration that tradition, practice, and functional necessity dictate.

More recently, however, a number of scholars have argued that transnational networks are often embedded in the more formal decisionmaking structures of traditional international organizations and therefore their structural and output characteristics cannot be as neatly contrasted with those of formal treaty regimes as was originally suggested (Slaughter and Zaring 2006). Moreover, they have noted the tendency for transnational networks to quickly morph into more routinized forms of organization that betray many of the same characteristics as classic international organizations (Zaring 2005). This understanding of global networks comes closer to the understanding of networks that prevails in research on the European Union. The work of a number of scholars, including several contributions to this volume (for example, that of Johannes Saurer), demonstrates that regulatory networks are omnipresent in the EU (Bignami 2005a, Cassese 2004, Chiti 2004, della Cananea 2004). As the Saurer chapter suggests, in many ways, the modus operandi of these EU regulatory networks is no different from that of traditional international institutions: they are generally established by formal legal instruments such as EU directives and regulations, their decisionmaking rules 
and procedures are fixed in advance, and their regulatory output can range from soft opinions to legally binding decisions.

What, then, is distinctive about transnational networks as compared to other types of international institutions? The answer rests in the practice of making and enforcing policy by way of routine contacts among civil servants in different countries, civil servants who are embedded in different bureaucracies and constitutional systems and who are tasked with managing specific policy areas both internally and externally. This sets transnational networks apart from high-level decisionmaking by heads of state, classically associated with international treaties, because in the latter case, the international component of policymaking is sporadic and control over policymaking is largely retained by national officials, with only occasional incursions from the broad directives contained in international treaties and the decisions of international tribunals. This also sets the work of transnational networks apart from that of international secretariats, which are generally staffed by career officials, have their own financial resources, and undertake their mission much as any centralized bureaucracy would. Transnational networks are characterized by the routine exchange of bureaucratic capacity and resources across state borders and for this reason, the policymaking process can be expected to be systematically different from other forms of international decisionmaking.

What types of networks are most likely to raise concerns related to fundamental rights? Of course, any type of policy decision taken by a transnational network, including those establishing general rules and programs, can tread upon fundamental rights. Thus, for instance, a (hypothetical) decision of the Basel Committee on Banking Supervision to establish a formula limiting the compensation of bankers would implicate the property interests of bankers. Similarly, changes to the Europol databank, through which national police exchange information on criminal suspects in the European Union, might very well implicate privacy rights. Yet the basic right to be free of arbitrary government determinations arises in the context of individualized decisionmaking, and in many legal systems, especially one as fluid as the international one, the opportunity to vindicate other fundamental rights such as the property and privacy interests just mentioned, most commonly presents itself in the context of an individual decision applied to a specific person or set of persons. Thus an analysis of the fundamental rights implications of transnational networks should, at the very least, begin with those networks that are involved in the process of making individualized determinations.

Enforcement networks most clearly fit this bill. They can involve the enforcement of classic regulatory policies, such as transatlantic cooperation on antitrust enforcement (Piilola 2003, Whytock 2005). They can also entail intelligence exchange, designed to facilitate the detention and arrest of suspects, by law enforcement and national security officials through bilateral arrangements and multilateral frameworks such as Interpol (Savino 2009) and Europol (Peers 2008). And there are many other examples, too numerous to review here.

\section{Safeguarding rights in transnational networks}

The operation of transnational enforcement and other types of networks has given rise to new puzzles for those committed to safeguarding individual rights against arbitrary government action. The central difficulty is the separation, in the network form of organization, between the government bodies responsible for collecting information and 
making policy decisions, and the national authority that ultimately takes the decision to arrest a suspect, freeze assets, impose a customs duty, or deny a subsidy. Due process, before and after such a decision is taken, is the main mechanism that the criminal and administrative law of liberal democracies has developed to keep check on policemen and bureaucrats and to ensure respect for a variety of fundamental rights when state authority is exercised. But these guarantees have not been systematically built into the transnational network form of organization, largely because of the old mindset of divided international and domestic spheres: in this account, the international sphere governs relations between states, the domestic one governs relations among individual citizens and between citizens and states. Therefore, because the very notion of individual rights and duties turns on citizenship in a national community, the protection of these rights and duties can only be afforded by the domestic rule-of-law institutions of the state.

Although this outlook might have sufficed in the past, when international cooperation was more sporadic and did not routinely enter into the details of individual cases, today it has generated a series of conundrums for the national officials charged with acting upon the information and decisions generated by transnational networks and the national courts tasked with checking those officials: should they automatically act upon the information and decisions generated by transnational networks, on the assumption that, at some point, individual rights and interests have been considered and adequately addressed? After all, to the extent that the participating network officials operate in the broader context of constitutional democracies, they can be expected to abide by fundamental rights guarantees. If not, and the executing national authorities decide to review the grounds for the determination independently, how can they guarantee the integrity of the review process when the bulk of the decisionmaking was handled by government agencies that escape their jurisdiction?

This problem of how and at what point in the transnational decisionmaking process to afford rights protection has recently come to fore with the UN Security Council's initiatives to combat terrorism. As is well known, in the late 1990s, the Security Council established a committee to administer a sanctions regime against individuals and entities associated with Osama bin Laden, the Al-Qaida network, and the Taliban. The process by which individuals and entities are listed and their assets then frozen is typical of a transnational enforcement network: domestic intelligence and law enforcement agencies communicate information on terrorism suspects to the national officials on the Sanctions Committee, this transnational committee then decides by consensus to place those suspects on an official list, at which point law national officials everywhere are under a duty to freeze the assets of the suspects that fall within their jurisdiction. The difficulty of affording adequate rights protection has been compounded by the policy area involved - counter-terrorism - and the secrecy that attends this area, confounding vigorous rights guarantees even when government action is exclusively domestic. Nonetheless, the dilemmas that the UN sanctions regime has created for the national bureaucracies and courts asked to freeze assets are typical of transnational enforcement networks more broadly speaking: can these national actors trust the network players to comply with fundamental rights guarantees, making their decisions worthy of enforcement, notwithstanding the protests of the individual concerned - in the case of the Sanctions Committee, the domestic intelligence agency that initially communicated the information and urged the listing, as well as the collective decision of the Sanctions Committee? If national rule-of-law 
institutions decide to go ahead and independently assess the rights claims, how can they overcome the handicap of one-step-removed information-gathering and decisionmaking and organize an effective review process? On the first question, the Supreme Court of Switzerland decided to defer to the UN network (Reich 2008), but not the European Court of Justice, which held in the Kadi case ${ }^{1}$ that the EU must independently afford due process rights for targeted individuals and entities (de Búrca 2009, della Cananea 2009). Now, however, the EU is faced with the second question of how to guarantee effective rights protection: due process requires that the terrorist suspects be able to contest the evidence used against them, but it is highly unlikely that either the Sanctions Committee or the United States, which originally requested the Kadi listing, will turn over the evidence to the European Commission, especially given its sensitive nature.

Although the UN Security Council's sanctions proceedings have recently brought attention to the difficulty of rights protections in transnational networks, it is by no means an isolated or novel phenomenon. Very similar issues are faced by intelligence and law enforcement agencies that exchange information for purposes of detaining individuals, making arrests, and freezing assets through bilateral arrangements or through international organizations like Interpol (Savino 2009). In the European Union, the fragmentation of decisionmaking power in enforcement networks has given rise to a directly related set of conundrums, which have been worked out in the case law of the European Court of Justice for over thirty years now. In the EU, the structure of the rights issue is slightly different because the decisions of EU institutions are subject to review by a central court - the European Court of Justice - in marked contrast to other international institutions like the UN Security Council and Europol. Two sets of issues have arisen in the EU context: how to allocate responsibility for judicial review of network decisions between national courts and the European Court of Justice and what fundamental rights law to apply to network decisions.

The puzzle of how to allocate jurisdiction between national courts and the European Court of Justice is directly connected to the dispersion of power among national regulators, the European Commission, and transnational committees of national regulators in networked policymaking. This issue has arisen mostly in the areas of agriculture and customs administration, where the decision to grant or withhold an agricultural subsidy or apply or waive a customs duty is the product of a particularly complex decisionmaking sequence involving national bureaucrats, the European Commission, and EU committees formed of national regulators (della Cananea 2004). The Court of Justice has held that individuals only have a right to challenge administrative decisions at the point at which they are 'directly affected' by the decision, meaning that there is no discretion left to the administrative authority to depart from the adverse outcome feared by the challenger. ${ }^{2}$ The result is that most challenges are brought in national courts, against local agricultural and customs authorities, because even though their decisions are based on the information and policies transmitted through the relevant EU network, it is the local bureaucrat that has the last say on whether to deny the subsidy or impose the customs duty. If, however, the national court wishes to overturn the administrative

1 Joined cases C-402 \& 415/05P, Kadi \& Al Barakaat Int'l Found. v. Council \& Comm'n, ECR I-6351.

2 See, for example, Case T-33/01, Infront WM AG v. Commission, 2005 ECR II-5897. 
decision, it is obliged to refer questions of EU law, including challenges to the network's regulatory framework, to the Court of Justice, through the preliminary reference system. ${ }^{3}$ This division of jurisdiction strikes a balance between distributing the task of safeguarding rights duties broadly, among all national courts, while at the same time retaining central control over the application of EU law and thus remaining faithful to the principle of equality. Yet it is not without its flaws: the test for allocating jurisdiction is fairly complex and therefore litigants face real uncertainty in deciding in what court to challenge the decisions of enforcement networks; it is unclear whether local courts are capable of fully reviewing the complex sequence of decisions that results in individualized determinations; and, if a preliminary reference is required, the time for obtaining an answer from the Court of Justice can be as much as two years.

The interplay between liberal rights and the decisions of enforcement networks has given rise to a second set of issues: what are the fundamental rights to be guaranteed by national courts and, in some instances, by the European Court of Justice when reviewing network enforcement decisions? Those guaranteed under the national constitution of the reviewing court or those guaranteed under EU law? And if the fundamental rights law of the EU applies, how is the content of that law to be determined? This is obviously a rich and complex debate, developed in the jurisprudence of the Court of Justice and national courts over decades and directly related to the question of supremacy. Suffice it to say that while national courts have come, for the most part, to accept that EU rights prevail, the content of those rights has been shaped by national traditions because of the interdependent nature of authority, both judicial and bureaucratic, and the need to accommodate different public law traditions in a governance structure based on policy networks. It is no coincidence that many of the early Court of Justice cases setting down constitutional principles such as human dignity, proportionality, and the right to property involved references from German administrative courts, exercising their power of review over network decisions and operating in the domestic context of a strong constitutional court. Likewise, as I have argued elsewhere, the due process rights that are afforded in individualized administrative proceedings have been shaped by the English tradition of natural justice by virtue of the same institutional logic of interdependent government authority (Bignami 2005b).

\section{Conclusion}

With this brief review of the experience with safeguarding liberal rights in the face of transnational networks, I have sought to highlight a couple of the key public law dilemmas that have arisen in the administration of networks. The dispersion of responsibility for decisionmaking has given rise to similar issues across different international regimes - the United Nations, the European Union, Interpol, and many others - such as the difficulty of protecting rights nationally when much of the information giving rise to administrative action is generated elsewhere. By the same token, EU networks raise a distinct set of issues compared to other transnational enforcement networks because they are policed by a combination of national courts and a central judicial body. Yet recently, some have urged the UN Sanctions Committee to establish a centralized process

3 See, for example, Case 314/85, Foto-Frost v. Hauptzollamt Lübeck-Ost, 1987 ECR 4199. 
involving an independent, expert panel through which terrorist suspects could petition for de-listing (Keller and Fischer 2009: 266). Similar calls can be heard for establishing centralized review of red alerts - the equivalent of arrest warrants - issued through the Europol information system (Savino 2009). Thus we might expect some of the same problems, related to the allocation of jurisdiction between national and supranational courts and to the creation of a common body of fundamental rights, to emerge in the public law of other transnational networks too.

\section{References}

Bignami, Francesca. 2005a. 'Transgovernmental Networks vs. Democracy: The Case of the European Information Privacy Network', Michigan Journal of International Law, 26: 807-68.

Bignami, Francesca. 2005b. 'Creating European Rights: National Values and Supranational Interests', Columbia Journal of European Law, 11: 241-352.

Cassese, Sabino. 2004. 'European Admininstrative Proceedings', Law and Contemporary Problems, 68: 21-36.

Chiti, Edoardo. 2004. 'Administrative Proceedings Involving European Agencies', Law and Contemporary Problems, 68: 219-36.

de Búrca, Gráinne 2009. 'The European Court of Justice and the International Legal Order after Kadi', Harvard International Law Journal 51: 1-49.

della Cananea, Giacinto. 2004. 'The European Union's Mixed Administrative Proceedings', Law and Contemporary Problems, 68: 197-217.

della Cananea, Giacinto. 2009. 'Global Security and Procedural Due Process of Law between the United Nations and the European Union: Yassin Abdullah Kadi \& Al Barakaat International Foundation v. Council', Columbia Journal of European Law, 15: 511-30.

Eilstrup-Sangiovanni, Mette. 2009. 'Varieties of Cooperation: Government Networks in International Security', in Networked Politics: Agency, Power, and Governance, Miles Kahler, ed., Ithaca, NY: Cornell University Press, 194-227.

Keller, Helen and Fischer, Andreas. 2009. 'The UN Anti-terror Sanctions Regime under Pressure', Human Rights Law Review, 9: 257-66.

Kingsbury, Benedict, Krisch, Nico and Stewart and Richard B. 2005. 'The Emergence of Global Administrative Law', Law and Contemporary Problems, 68: 15-61.

Lindseth, Peter L. 2006. 'Agents without Principals?: Delegation in an Age of Diffuse and Fragmented Governance', in Reframing Self-regulation in European Private Law, Fabrizio Cafaggi, ed., Alphen aan den Rijn, The Netherlands: Kluwer Law International, 107-30.

Peers, Steve. 2008. EU Justice and Home Affairs Law, Oxford: Oxford University Press.

Piilola, Anu. 2003. 'Assessing Theories of Global Governance: A Case Study of International Anti-trust Regulation', Stanford Journal of International Law, 39: 208-51.

Raustiala, Kal. 2002. 'The Architecture of International Cooperation: Transgovernmental Networks and the Future of International Law', Virginia Journal of International Law, 43: 1-92.

Reich, Johannes. 2008. 'Due Process and Sanctions Targeted against Individuals Pursuant to Resolution 1267 (1999)', Yale Journal of International Law, 31: 505-11.

Savino, Mario. 2009. 'Global Administrative Law and "Soft" Powers: The Uncomfortable Case of Interpol Red Notice', unpublished manuscript on file with author.

Singer, David Andrew. 2007. Regulating Capital: Setting Standards for the International Financial System, Ithaca, NY: Cornell University Press.

Slaughter, Anne-Marie. 2004. A New World Order, Princeton, NJ: Princeton University Press.

Slaughter, Anne-Marie and Zaring, David. 2006. 'Networking Goes International: An Update', Annual Review of Law and Social Sciences, 211-29.

Verdier, Pierre-Hughes. 2009. 'Transnational Regulatory Networks and their Limit', Yale Journal of International Law, 34: 113-172.

Whytock, Christopher. 2005. 'A Rational Design Theory of Transgovernmentalism: The Case of E.U.-U.S. Merger Review Cooperation', Boston University International Law Journal, 23: 1-53.

Zaring, David. 1998. 'International Law by Other Means: The Twilight Existence of International Financial Organizations', Texas International Law Journal, 33: 281-330.

Zaring, David. 2005. 'Informal Procedure, Hard and Soft in International Administration', Chicago Journal of International Law, 5: 547-603. 